\title{
ГЕОЭКОЛОГИЯ GEOECOLOGY
}

DOI 10.22363/2313-2310-2021-29-2-162-173

УДК 556.5.04:556.114

Научная статья / Research article

\section{Исследование роли природных и антропогенных факторов в формировании качества воды малых рек на примере р. Велетьмы Нижегородской области}

\author{
М.В. Смирнова ${ }^{\otimes}$, А.И. Батанина \\ Волюский государственный университет водного транспорта, \\ Российская Федераиия, 603950, Нижний Новгород, ул. Нестерова, д. 5 \\ 凶igoninam@yandex.ru
}

Аннотация. Малые реки Центральной России зачастую испытывают высокую антропогенную нагрузку, при этом их изученность и меры, принимаемые для их сохранения, несравнимо скромнее, чем для крупных водных артерий. В исследовании на примере p. Велетьмы Нижегородской области рассмотрены факторы, влияющие на формирование качества вод малой реки. Дана эколого-географическая характеристика р. Велетьмы. Показано, что действующая методика оценки качества вод крупных рек по удельному комбинаторному индексу загрязненности воды не позволяет определить, какой вклад в ухудшение качества воды вносит антропогенная нагрузка, а какой - природные факторы. Выполнены исследования ряда физико-химических характеристик вод р. Велетьмы, которые показали, что на коротком участке реки, составляющем менее 400 м, происходят значительные изменения физико-химического состава воды, по некоторым показателям достигающие 45-95 \%. Столь значительные изменения связаны, с одной стороны, с влиянием очистных сооружений г. Навашино, а с другой стороны, с особым расположением оз. Зеленого на пути реки. На спутниковых снимках зоны впадения Велетьмы в озеро зафиксирован плюм. Выдвинуто предположение о протекании в озере процессов, характерных для впадения крупных и средних рек в моря и озера, называемых маргинальным фильтром, при котором происходит задержание не только взвешенных, но и растворенных примесей, что подтверждается лабораторными исследованиями.

Ключевые слова: Велетьма, малые реки, качество воды, физико-химические показатели воды, плюм

Благодарности и финансирование. Работа выполнена при поддержке Научнообразовательного центра Нижегородской области «Техноплатформа 2035» в рамках договора № 16-11-2021/54 от 16.11.2021 г., а также при грантовой поддержке Русского географического общества в рамках договора № 07/2020-Р от 29.07.2020 г.

История статьи: поступила в редакцию 22.12.2020; принята к публикации 10.01.2021.

(С) Смирнова М.В., Батанина А.И., 2021

(c) () This work is licensed under a Creative Commons Attribution 4.0 International License https://creativecommons.org/licenses/by/4.0/ 
Для цитирования: Смирнова М.В., Батанина А.И. Исследование роли природных и антропогенных факторов в формировании качества воды малых рек на примере p. Велетьмы Нижегородской области // Вестник Российского университета дружбы народов. Серия: Экология и безопасность жизнедеятельности. 2021. Т. 29. № 2. С. 162-173. http://dx.doi.org/10.22363/2313-2310-2021-29-2-162-173

\title{
Study of the role of natural and anthropogenic factors in the formation of water quality in small rivers on the example of the Veletma river in the Nizhny Novgorod region
}

\author{
Maria V. Smirnova $₫$, Anastasia I. Batanina \\ Volga State University of Water Transport, \\ 5 Nesterova St, Nizhny Novgorod, 603950, Russian Federation \\ $\bigotimes$ igoninam@yandex.ru
}

\begin{abstract}
Small rivers of Central Russia often experience a high anthropogenic pressure, and at the same time their study and measures taken to preserve them are incomparably more modest than for large rivers. On the example of the Veletma river in the Nizhny Novgorod region, the factors affecting the formation of the water quality of the small river are considered. The ecological and geographical characteristics of the Veletma river are given. It is shown that the current methodology for assessing the water quality of large rivers by the Specific Combinatorial Water Pollution Index does not allow to determine what is the contribution of anthropogenic pressure to the deterioration of water quality, and what is the contribution of natural factors. Studies of a number of physical and chemical characteristics of the waters of the Veletma river have shown that on a short section of the river, which is less than $400 \mathrm{~m}$, there are significant changes in the physical and chemical composition of water, reaching $45-95 \%$. Such significant changes are associated on the one hand with the influence of the treatment facilities of the city of Navashino, and on the other hand, with the special location of the lake Zelenoe in the path of the river. Satellite images of the Veletma's confluence with the lake Zelenoe show the plume. It is suggested that the lake is characterized by the same processes that take place in the confluence of large and medium-sized rivers into the seas and lakes, called marginal filter, in which not only suspended but also dissolved impurities are retained. This fact is confirmed by laboratory studies.
\end{abstract}

Keywords: small rivers, the Veletma river, water quality, physical and chemical characteristics of water, plume

Acknowledgements and Funding. The work was carried out with the support of the Scientific and Educational Center of the Nizhny Novgorod region "Technoplatform 2035" under the agreement No. 16-11-2021/54 dated 11/16/2021, as well as with the grant support of the Russian Geographical Society under the agreement No. 07/2020-R dated 07/29/2020.

Article history: received 22.12.2020; revised 10.01.2021.

For citation: Smirnova MV, Batanina AI. Study of the role of natural and anthropogenic factors in the formation of water quality in small rivers on the example of the Veletma river in the Nizhny Novgorod region. RUDN Journal of Ecology and Life Safety. 2021; 29(2):162-173. (In Russ.) http://dx.doi.org/10.22363/2313-2310-2021-29-2-162-173

\section{Введение}

Малые реки Нижегородской области до сих пор остаются малоизученными, несмотря на то что длительное время используются местным населением для различных целей. Многие исследователи поддерживают мнение о 
том, что гидроэкологические изменения в крупных реках являются следствием изменений малых рек, питающих крупные водотоки [1-3]. Существуют данные о том, что вклад малых равнинных рек в загрязнение биогенными элементами - азотом и фосфором - крупных водных артерий может составлять от 40 до 90 \% за счет диффузного загрязнения, поступающего с площади водосбора малых рек [4]. Поэтому экологическое состояние р. Велетьмы, расположенной в условиях сравнительно высокой плотности населения $(32,5$ чел./км²) и являющейся правым притоком еще более густонаселенной р. Оки, является важным фактором благополучия значительной части населения югозапада Нижегородской области. Однако, в отличие от хорошо изученных крупных рек, данные об экологическом состоянии р. Велетьмы и тем более о динамике этого состояния крайне скудны и обрывочны.

Целью исследования стала попытка систематизировать существующие данные об экологическом состоянии р. Велетьмы, а также провести физикохимические исследования воды в реке в районе г. Навашино и оценить вклад природных и антропогенных факторов в формирование качества ее вод.

\section{Характеристика района исследований и состояние изученности}

Река Велетьма протекает в юго-западной части Нижегородской области. По данным государственного водного реестра России, она относится к Окскому бассейновому округу, водохозяйственный участок реки - р. Ока от впадения р. Мокша до впадения р. Тёша. Длина реки - 99 км, площадь водо-

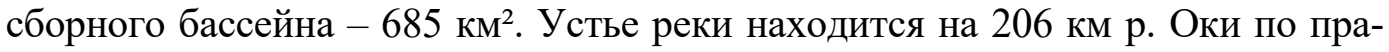
вому берегу. Исток реки находится южнее с. Чупалейка, в 28 км к юго-востоку от г. Выксы. Генеральное направление течения - северо-запад. Река имеет два притока: левый, на 44 км - р. Ильмис протяженностью 12 км и правый, на 60 км - р. Толкава протяженностью 21 км. По данным [5], Велетьма имеет также 44 притока длиной менее 10 км и общей длиной 86 км. На водосборе p. Велетьмы расположены 29 озер общей площадью зеркала 5,20 км².

Питание реки, как и у большинства рек возвышенного Нижегородского Правобережья Волги, главным образом родниковое. Весной в результате быстрого сбора талых снеговых вод по оврагам и склонам вода из реки быстро уходит, поэтому для Велетьмы характерен значительный перепад уровней воды между весенним половодьем и летней меженью. По берегам - леса, пойма местами заболочена. Дно реки состоит из глины и нанесенного песка, в некоторых местах дно илистое. Велетьма в своем верхнем течении протекает по суглинистым дерново-подзолистым и болотным почвам, а в среднем и нижнем течениях в основном по супесчаным дерново-подзолистым почвам [6]. В нижнем течении Велетьма входит в обширную Приокскую пойму, где на реке стоят г. Навашино и с. Большое Окулово. Впадает в старицу р. Оки ниже г. Мурома (рис. 1). Крупные населенные пункты по берегам p. Велетьмы: с. Чупалейка, пгт Велетьма и рыбхоз Велетьма, с. Саваслейка и расположенная к юго-западу от села авиабаза, с. Большое Окулово, г. Навашино и с. Малое Окулово.

В районе г. Навашино р. Велетьма впадает в оз. Зеленое с востока, а затем вытекает из него на западе. Само озеро имеет пойменно-тыловое проис-

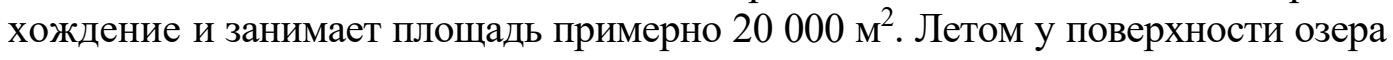


наблюдаются сине-зеленые водоросли, которые вызывают цветение водоема. По утверждениям местных жителей, именно по этой причине озеро получило название «Зеленое». Этот факт может свидетельствовать о высокой вероятности привнесения в озеро большого количества биогенных веществ, источником которых могут быть хозяйственно-бытовые стоки или сельское хозяйство.

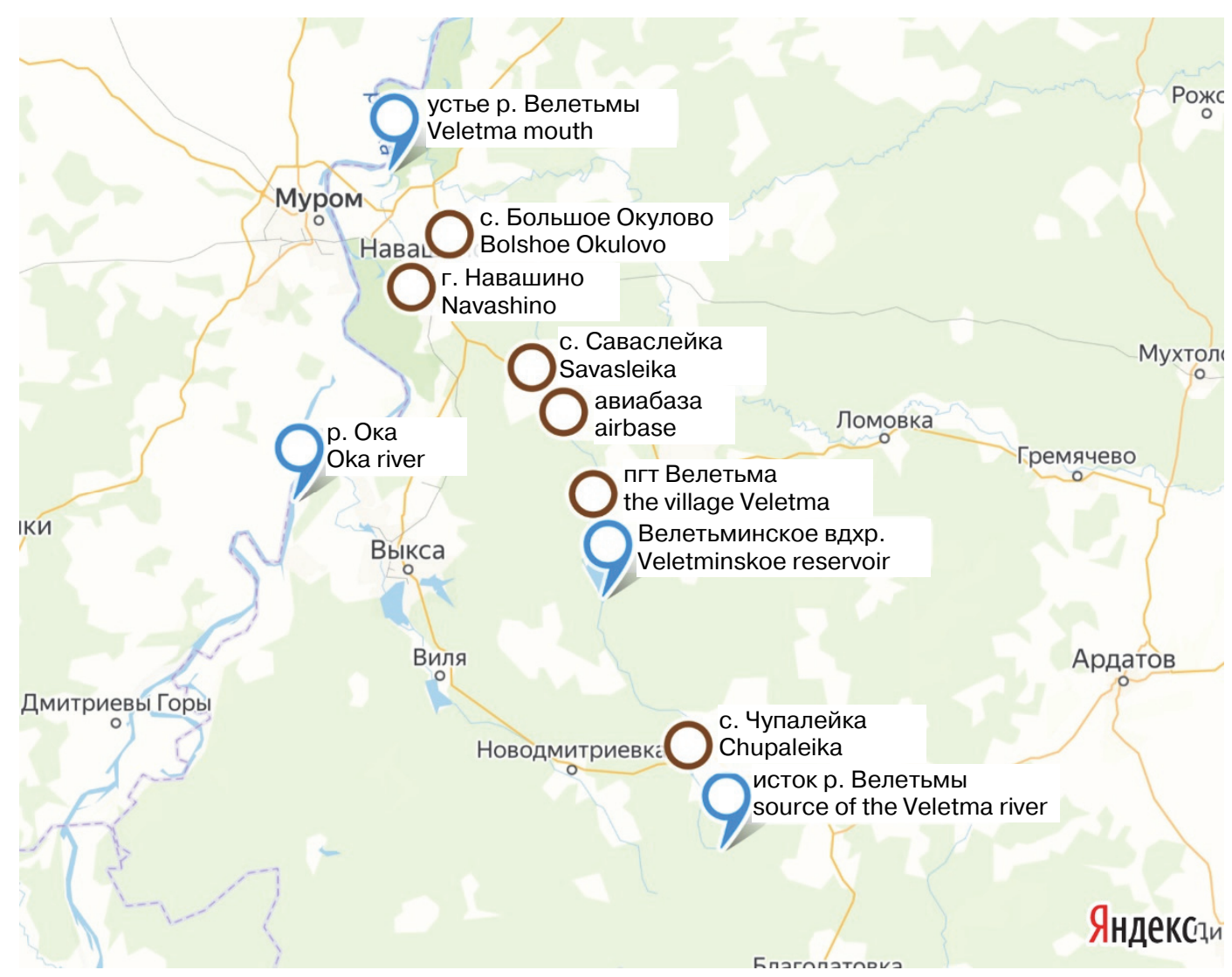

Рис. 1. Географическое положение р. Велетьмы

Figure 1. Geographical position of the Veletma river

Действительно, на берегу оз. Зеленого расположены биологические очистные сооружения (БОС) г. Навашино ООО «Водоканал». Проектная производительность очистных сооружений $-8,8$ тыс. м $^{3}$ в сутки, фактическая $-1,8$ тыс. $\mathrm{m}^{3}$ в сутки (по данным на 2016 г.). Объем пропущенной воды через очистные сооружения в 2018 г. составил 713,39 тыс. м ${ }^{3}$, а в $2019-609,66$ тыс. м³. Выпуск очищенных сточных вод БОС производится непосредственно в озеро. Общие сведения о глубине очистки и качестве сбрасываемых из БОС очищенных сточных вод приведены в табл. 1.

Как видно из таблицы, не все показатели после очистки достигают нормативных значений ${ }^{1}$, в частности БПК (норма 2,1 мг/дм³), СПАВ (норма

${ }^{1}$ Приказ Минсельхоза России от 13.12.2016 г. № 552 (ред. от 10.03 .2020 г.) «Об утверждении нормативов качества воды водных объектов рыбохозяйственного значения, в том числе нормативов предельно допустимых концентраций вредных веществ в водах водных объектов 
0,1 мг/дм $\left.{ }^{3}\right)$, азот аммонийный $\left(0,4\right.$ мг/дм $\left.{ }^{3}\right)$. Но и другие показатели значительно превышают содержание таковых в реках Нижегородской области, например фосфаты, которые являются главным фактором развития синезеленых водорослей ${ }^{2}$.

Таблица

\section{Данные о качестве очистки сточных вод на БОС г. Навашино}

\begin{tabular}{lcc}
\hline \multicolumn{1}{c}{ Наименование загрязнений } & До очистки, мг/дм & После очистки, мг/дм $^{3}$ \\
\hline Биохимическое потребление & 174 & 15 \\
кислорода (БПК ${ }_{5}$ ) & 194 & 15 \\
Взвешенные вещества & $6,5-8,5$ & $6,5-8,5$ \\
Водородный показатель рН, ед. & 1,2 & 0,025 \\
Нефтепродукты & 17 & 16.5 \\
Хлориды & 20 & 1,32 \\
Сульфаты & 4 & 4 \\
Синтетические поверхностно- & & 0,003 \\
активные вещества (СПАВ) & 0,12 & 0,002 \\
Железо & 0,002 & 0,05 \\
Медь & 0,05 & 10 \\
Цинк & 19 & 1,2 \\
Азот аммонийный & 1,73 & \\
Фосфаты & & \\
\hline
\end{tabular}

Table

Data on the quality of wastewater treatment at the treatment facilities of the city of Navashino

\begin{tabular}{|c|c|c|}
\hline Paramater & Before treatment, $\mathrm{mg} / \mathrm{dm}^{3}$ & After treatment, $\mathrm{mg} / \mathrm{dm}^{3}$ \\
\hline Biochemical oxygen demand (BOD5) & 174 & 15 \\
\hline Suspended solids & 194 & 15 \\
\hline $\mathrm{pH}$ level & $6.5-8.5$ & $6.5-8.5$ \\
\hline Oil products & 1.2 & 0.025 \\
\hline Chlorides & 17 & 16.5 \\
\hline Sulphates & 20 & 1.32 \\
\hline $\begin{array}{l}\text { Synthetic surface active substances } \\
\text { (surfactants) }\end{array}$ & 4 & 4 \\
\hline Ferric iron & 0.12 & 0.003 \\
\hline Cuprum & 0.002 & 0.002 \\
\hline Zinc & 0.05 & 0.05 \\
\hline Ammonium nitrate & 19 & 10 \\
\hline Phosphates & 1.73 & 1.2 \\
\hline
\end{tabular}

Одной из актуальных проблем р. Велетьмы является уменьшение ее водности: по наблюдениям жителей с. Большое Окулово, средние глубины ее в этом районе за последние 10 лет уменьшились примерно на 70 см, а дно реки заилилось. В [2] подтверждено сокращение протяженности рус-

рыбохозяйственного значения» (зарегистрировано в Минюсте России 13.01.2017 г. № 45203. URL: http://pravo.gov.ru/proxy/ips/?searchres $=\&$ bpas $=$ cd00000\&intelsearch $=\%$ CF $\% \mathrm{~F} 0 \% \mathrm{E} 8 \% \mathrm{EA} \% \mathrm{E} 0 \% \mathrm{E}$ $7+\% \mathrm{CC} \% \mathrm{E} 8 \% \mathrm{ED} \% \mathrm{~F} 1 \% \mathrm{E} 5 \% \mathrm{~EB} \% \mathrm{FC} \% \mathrm{~F} 5 \% \mathrm{EE} \% \mathrm{E} 7 \% \mathrm{E} 0+\% \mathrm{D} 0 \% \mathrm{EE} \% \mathrm{~F} 1 \% \mathrm{~F} 1 \% \mathrm{E} 8 \% \mathrm{E} 8+\% \mathrm{EE} \% \mathrm{~F} 2$ $+13.12 .2016+\% \mathrm{E} 3 .+\% \mathrm{E} 2 \% 84 \% 96+552 \&$ sort=-1 (дата обращения: 10.12.2020).

${ }^{2}$ Государственный доклад «Состояние окружающей среды и природных ресурсов Нижегородской области» // Ежегодник / Министерство экологии и природных ресурсов Нижегородской области, 2011-2018 гг. URL: https://ecology.government-nnov.ru/activity/1604/ (дата обращения: 10.12.2020). 
ловой сети элементарных водотоков в водосборном бассейне р. Велетьмы, напрямую связанной с водностью реки. Одной из выявленных причин этого процесса является сокращение лесистости на территории ее водосборного бассейна. К сожалению, данные о годовом стоке р. Велетьмы или о ее водности отсутствуют [7]. В то же время, по данным [8], правобережные притоки нижнего течения Оки характеризуются значениями модуля стока 4-5 л/(c·км²). Тогда, по грубым оценкам, годовой сток р. Велетьмы может составлять от 86747 до 108093 тыс. м³.

\section{Материалы и методы}

Для исследования влияния таких факторов, как разбавление речной воды в озере и влияние очистных сооружений на гидроэкологические показатели р. Велетьмы, осенью 2020 г. был выполнен отбор проб в двух створах: выше впадения реки в оз. Зеленое и ниже сбросной трубы БОС г. Навашино (рис. 2).

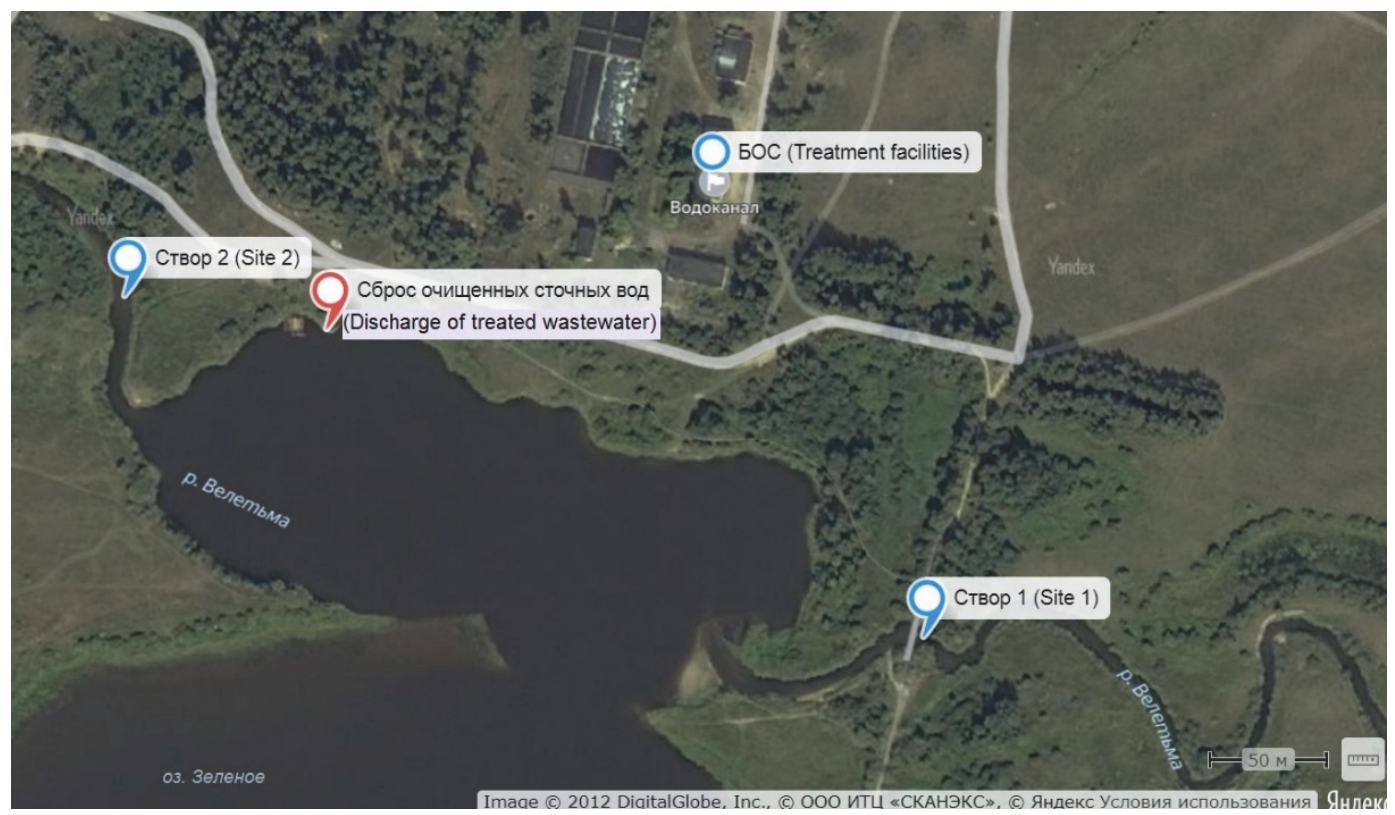

Рис. 2. Расположение створов отбора проб и выпуска очищенных сточных вод БОС г. Навашино (схема создана на основе сервиса «Яндекс.карты»)

Figure 2. Location of the sampling points and the release of treated wastewater from the Navashino treatment facilities (the scheme was created on the basis of the Yandex.maps)

Пробы исследовались в лаборатории «Экология» ФГБОУ ВО «Волжский государственный университет водного транспорта». Перечень анализируемых характеристик включал в себя цветность, прозрачность, водородный показатель $\mathrm{pH}$, солесодержание, мутность, общее железо, жесткость и содержание легкоокисляемой органики по величине биохимического потребления кислорода (БПК 5 ). Цветность определялась по хром-кобальтовой шкале, прозрачность - по методу «шрифта», концентрация растворенного кислорода на нулевой и пятый день инкубации проб на показатель БПК5 измерялись с помощью кислородомера «МАРК-302Э». Измерение общего солесодержания про- 
изводилось на кондуктометре «Анион-4120», водородного показателя - с помощью рН-метра «МАРК-901». Фотометрическое измерение мутности производилось на приборе «Эксперт-001», измерение концентрации железа проводилось сульфосалициловой кислотой с фотометрическим окончанием, а жесткости воды - титриметрическим методом.

\section{Обсуждение результатов}

Как показал обзор литературных источников, данные об экологическом состоянии р. Велетьмы и ее физико-химическом составе крайне скудные. Единственные официальные сведения о качестве воды в реке содержатся в ежегодном докладе о состоянии окружающей среды в Нижегородской области, составляемом Верхне-Волжским УГМС 3 . По данным этого доклада, измерения на p. Велетьма проводятся в двух створах, расположенных выше и ниже г. Навашино. По результатам измерений в этих створах, качество вод р. Велетьма в период с 2011 по 2018 г. постепенно ухудшалось с разряда «А» класса 3 «загрязненные» до разряда «А» класса 4 «грязные». Однако такая унифицированная оценка не позволяет определить, какой вклад в ухудшение качества воды в реке вносит антропогенная нагрузка, а какой - природные факторы. В частности, повышенные концентрации железа в водах р. Велетьмы могут носить природный характер. Аналогичный вывод был получен в [9] при сравнительном анализе экологического состояния р. Кудьмы и Линды Нижегородской области.

По результатам анализов проб воды построена восьмилепестковая диаграмма, характеризующая следующие показатели: БПК 5 , железо общее, жесткость, прозрачность, цветность, $\mathrm{pH}$, общее солесодержание и мутность в верхнем и нижнем створах (рис. 3 ).

Изменение БПК 5 между верхним и нижним створами оказалось весьма значительным и составило $95 \%$ - с 2,19 до 4,28 мгО $2 /$ л. Это говорит о том, что в воде нижнего створа после выпуска очищенных сточных вод высокое содержание органических веществ, хотя все же не такое высокое, как в неочищенной сточной воде (см. таблицу). Результаты наблюдений ВерхнеВолжского УГМС подтверждают факт периодического повышения показателя БПК 5 в створе после выпуска БОС 4 .

Повышенное содержание железа в природных водах Навашинского района типично для многих подземных и поверхностных источников средней полосы России [10]. В нижнем створе концентрация железа снизилась на $30 \%$ по сравнению с верхним - с 1 до 0,7 мг/дм ${ }^{3}$, что все еще недостаточно для нужд как питьевого $\left(0,3\right.$ мг/дм $\left.{ }^{3}\right)$, так и рыбохозяйственного $\left(0,1\right.$ мг/дм $\left.{ }^{3}\right)$ водопользования. Такое снижение может быть связано с тем, что в нижнем створе происходит разбавление очищенными от железа сточными водами (очистка БОС составляет до 0,003 мг/дм³).

${ }^{3}$ Государственный доклад «Состояние окружающей среды и природных ресурсов Нижегородской области» // Ежегодник / Министерство экологии и природных ресурсов Нижегородской области, 2011-2018 гг. URL: https://ecology.government-nnov.ru/activity/1604/ (дата обращения: 10.12.2020).

${ }^{4}$ Там же. 
Жесткость после сброса сточных вод увеличилась, но незначительно, в пределах погрешности измерений. В целом вода мягкая, содержание солей жесткости в ней менее 3 мг-экв/дм³ телю может объясняться тем, что на очистных сооружениях не происходит очистки от солей жесткости.

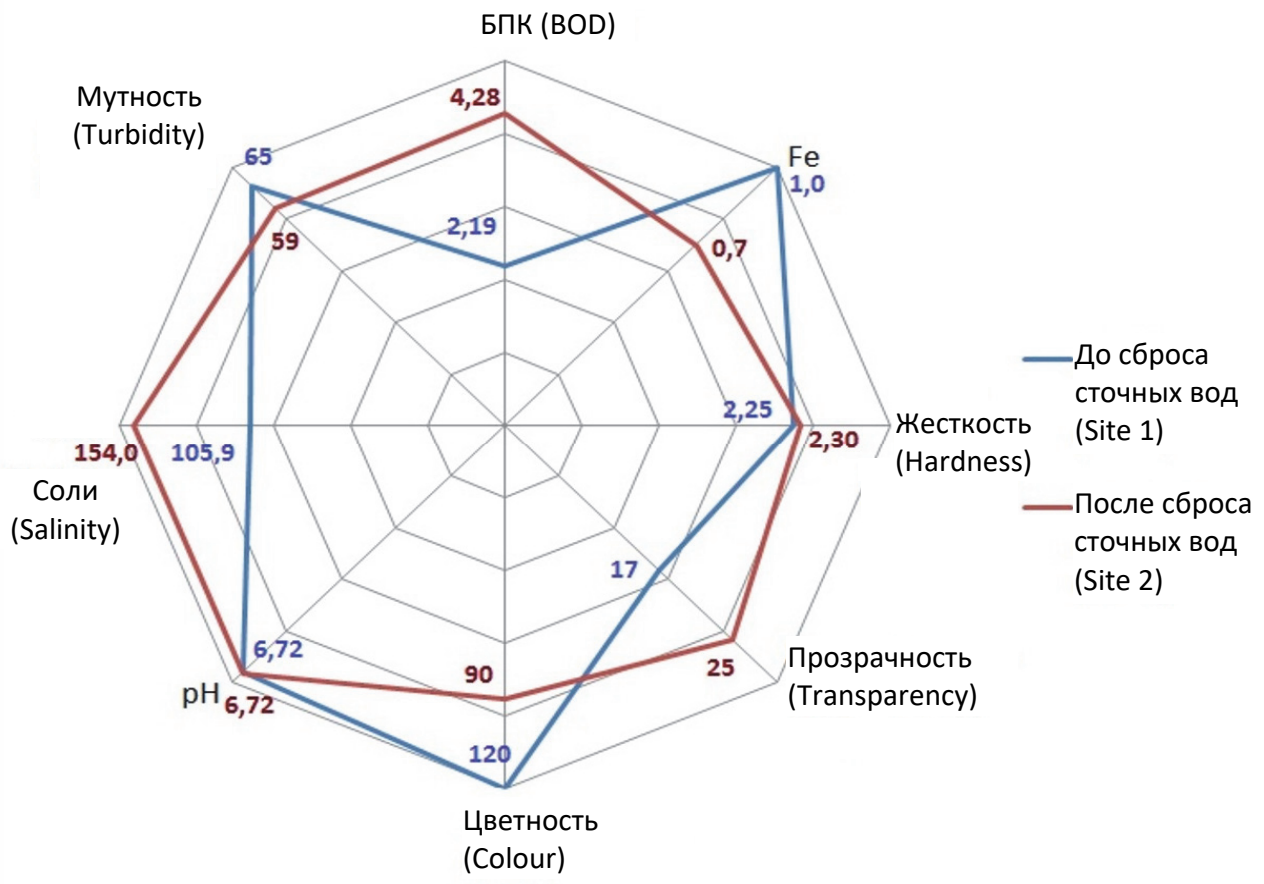

Рис. 3. Результаты измерений показателей качества воды в верхнем и нижнем створах Figure 3. Results of water quality measurements in the upper and lower sections

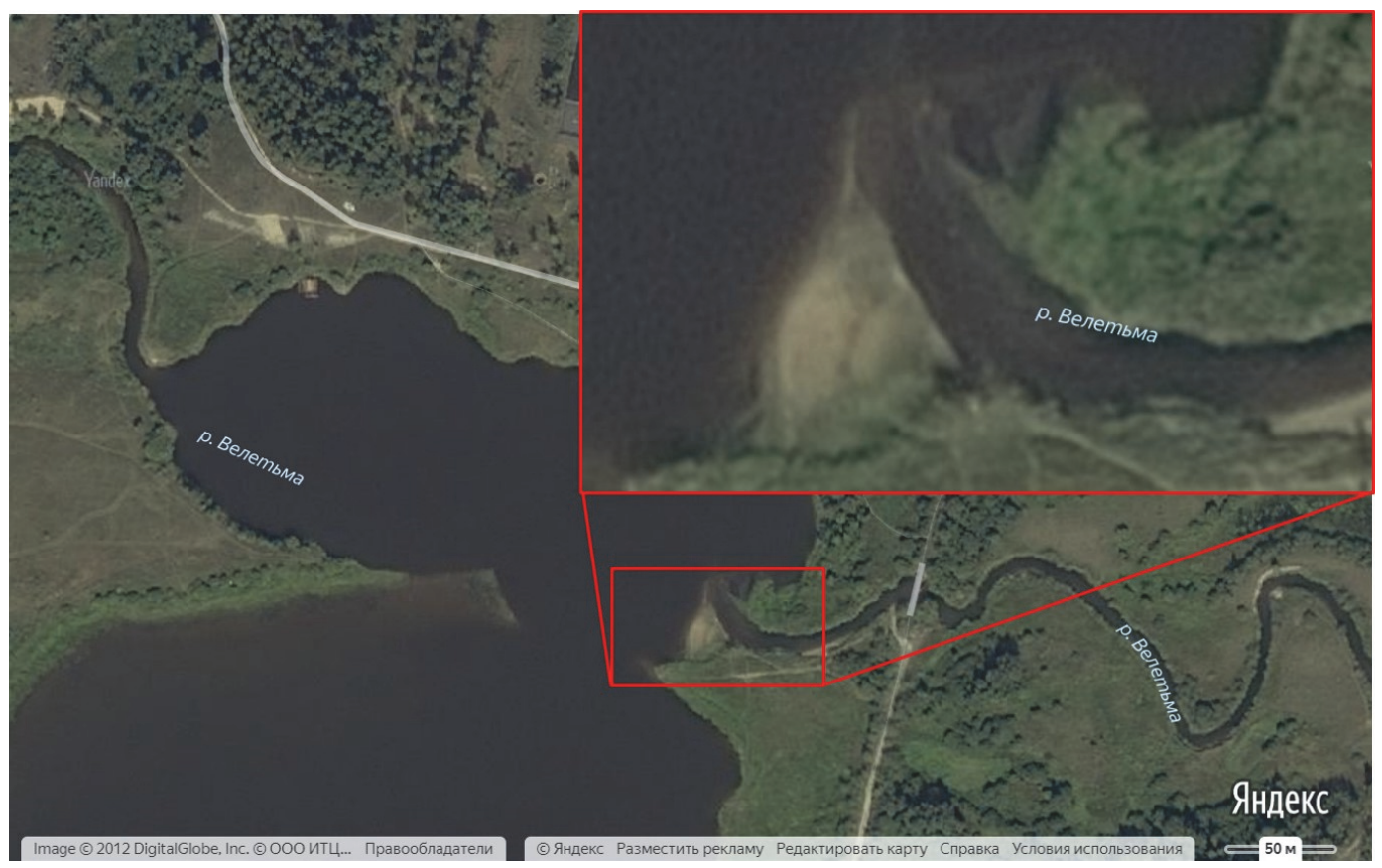

Рис. 4. Область выноса Велетьмой взвеси в оз. Зеленое (на основе сервиса «яндекс.карты») Figure 4. The area of removal and deposition of suspended substances from the Veletma river to the lake Zelenoe (based on the Yandex.maps) 
Прозрачность по методу «шрифта» в нижнем створе увеличилась на 47 \% - с 17 до 25 см. Это может быть связано с замедлением движения воды при впадении р. Велетьмы в оз. Зеленое, где речной поток успокаивается и взвеси начинают оседать на дно. Этот факт подтверждается спутниковыми снимками озера, на которых виден характерный плюм, в котором происходит активное осаждение взвесей, принесенных рекой (рис. 4). Известно, что подобные приустьевые зоны смешения крупных рек и озерных или морских вод играют роль так называемого маргинального фильтра $[11 ; 12]$, который удерживает до 90-95 \% взвешенных и до 20-40 \% растворенных веществ, поступающих в озеро или море с речным стоком.

Цветность в нижнем створе уменьшилась на $25 \%$ по сравнению с верхним - с 120 до 90 цветности. С одной стороны, это может быть связано с разбавлением воды очищенными сточными водами. Но их годовой расход не превышает $1 \%$ от годового стока р. Велетьмы. С другой стороны, в своем нижнем течении, после с. Большое Окулово, Велетьма протекает по супесчаным дерново-подзолистым почвам, которые не придают воде большой цветности, в то время как в верхнем и среднем течениях река насыщается гуминовыми кислотами от дерново-подзолистых и особенно болотных почв. Кроме того, можно предположить, что озеро играет роль «маргинального фильтра» для р. Велетьмы, тогда снижение цветности воды на 25 \% хорошо согласуется с оценками [11] о количестве осаждаемых им растворенных веществ, поступающих из реки.

Водородный показатель $\mathrm{pH}$ как в верхнем, так и в нижнем створах составил 6,72 единиц, что говорит о слабокислой среде, но все же не выходящей за допустимые пределы $(6,5-8,5)$. Кислотность воды так же, как и цветность, связана со свойствами почв, по которым она протекает. Неизменность значений $\mathrm{pH}$ в верхнем и нижнем створах говорит об отсутствии влияния на этот показатель как оз. Зеленого, так и очищенных сточных вод БОС.

Интересен тот факт, что солесодержание после сброса сточных вод увеличилось на $45 \%$ - с 105,9 до 154,0 мг/дм³. Вероятнее всего, соли привносятся в реку со сбросом очистных сооружений. Действительно, по данным таблицы, БОС не удаляют из сточной воды соли, при этом степень минерализации городских сточных вод может колебаться от 400 до 800 мг/дм ${ }^{3}$, а во многих производственных сточных водах даже достигать 1000-3000 мг/дм³ [13]. Несмотря на то что норматива по предельному содержанию солей в сбрасываемых водах не существует, столь резкое увеличение солесодержания может угнетать жизнедеятельность гидробионтов.

Мутность в нижнем створе снизилась на $9 \%$ по сравнению с верхним створом - с 65 до 59 мг/дм³. Это, аналогично улучшению прозрачности, может быть связано как со сбросом очистными сооружениями менее мутных вод (по данным таблицы, мутность после очистки составляет всего 15 мг/дм³), так и с осаждением взвешенных веществ в оз. Зеленом за счет успокоения течения в нем. 


\section{Заключение}

Как показал обзор литературных источников, данные об экологическом состоянии р. Велетьма и ее физико-химическом составе крайне скудные. Единственные официальные сведения о качестве воды в реке содержатся в ежегодном докладе о состоянии окружающей среды в Нижегородской области, составляемом Верхне-Волжским УГМС. Согласно ему, измерения на p. Велетьма проводятся в двух створах - выше и ниже г. Навашино, и по результатам этих измерений воды р. Велетьмы в последние годы относились к «грязным», класс 4A, причем качество вод ухудшалось. Тем не менее такая унифицированная оценка не позволяет определить, какой вклад в ухудшение качества воды в реке вносит антропогенная нагрузка, а какой - природные факторы. В частности, повышенное содержание в воде железа и повышенные цветность и мутность воды в данном случае носят природный характер и не отражают степень антропогенного влияния на водоток.

В процессе исследования проб воды, взятых на р. Велетьме выше оз. Зеленого и ниже очистных сооружений г. Навашино, установлено влияние на качество речной воды как самого озера, так и очистных сооружений. На коротком участке реки, составляющем менее 400 м, происходят значительные изменения физико-химического состава воды, которые по некоторым показателям достигают 45-95 \%. Благодаря особому относительному расположению, оз. Зеленое и очистные сооружения г. Навашино делят р. Велетьму на два различных по своим характеристикам потока. Присутствие озера на пути велетьминского водотока формирует благоприятные условия для осаждения взвешенных веществ, что подтверждается спутниковыми снимками. На основании наблюдаемого на снимках характерного речного плюма и по данным о снижении показателей содержания растворенных и коллоидных веществ в реке до и после озера, выдвинуто предположение о действии так называемого маргинального фильтра в зоне впадения Велетьмы в оз. Зеленое. Поэтому благодаря озеру, кроме осаждения взвесей, в этой зоне может происходить задержание 20-40 \% растворенных веществ, приносимых рекой [11]. Так, в отобранных пробах наблюдалось снижение цветности воды на $25 \%$, а железа - на $30 \%$.

Негативное влияние очистных сооружений г. Навашино проявляется в повышении минерализации воды на $45 \%$ и увеличении содержания органических веществ по величине БПК 5 на $95 \%$.

Таким образом, на примере описанного участка малой реки показан уровень антропогенного загрязнения малых рек, протекающих в сельской местности Центрального Поволжья, а также факторы, позволяющие сохранить уникальную способность малых водотоков к самоочищению.

\section{Список литературы}

[1] Ткачев Б.П., Булатов В.И. Малые реки: современное состояние и экологические проблемы: аналитический обзор / ГПНТБ СО РАН. Новосибирск, 2002. 114 с.

[2] Асташин А.Е., Соткина С.А., Бадьин М.М., Рыюсов Е.В., Самойлов А.В. Динамика развития сети элементарных водотоков севера лесостепной зоны Нижегородской области (на примере водосборного бассейна р. Сундовик) в период 1984-2016 гг. // 
Вестник Волжской государственной академии водного транспорта. 2016. № 48. C. 15-24.

[3] Смирнова (Игонина) М.В., Чебан Е.Ю., Володченко Е.В., Бердникова Е.Ю., Солина Е.С. Гидроэкологические исследования участков Горьковского и Чебоксарского водохранилищ с притоками в летний период 2017 года // Вестник ВГАВТ. 2017. Вып. 4 (53). С. 98-108.

[4] Ясинский С.В., Венищианов Е.В., Вишневская И.А. Диффузное загрязнение водных объектов и оценка выноса биогенных элементов при различных сценариях землепользования на водосборе // Водные ресурсы. 2019. Т. 46. № 2. С. 232-244.

[5] Ресурсы поверхностных вод СССР. Гидрологическая изученность. Т. 10. ВерхнеВолжский район / под ред. В.П. Шабан. Ленинград: Гидрометиздат, 1966. 528 с.

[6] Асташин А.Е., Бадьин М.М., Самойлов А.В., Рыљсов Е.В., Власов А.В., Фомина А.И. Ландшафтная дифференциация территории водосборного бассейна р. Велетьма Нижегородской области // Естественные и технические науки. 2019. № 1. С. 90-95.

[7] Основные гидрологические характеристики рек бассейна Верхней Волги: научноприкладной справочник / под ред. В.Ю. Георгиевского. Ливны: Изд. Мухаметов Г.В.; ГГИ, 2015. $129 \mathrm{c.}$

[8] Джамалов Р.Г., Мягкова К.Г., Никаноров А.М., Решетняк О.С., Сафронова Т.И., Трофимчук M.M. Гидрохимический сток рек бассейна Оки // Вода и экология: проблемы и решения. 2017. № 4 (72). С. 26-39. http://dx.doi.org/10.23968/23053488.2017.22.4.26-39

[9] Терешина М.А., Соколов Д.И., Ерина О.Н., Вилимович Е.А. Природный фон или антрогогенные загрязнения: формирование качества воды рек Линды и Кудьмы // Проблемы экологии Волжского бассейна: труды 4-й Всероссийской научной конференции. Н. Новгород: ФГБОУ ВО «ВГУВТ», 2019. С. 28.

[10] Онищенко Г.Г. Гигиеническая оценка обеспечения питьевой водой населения Российской Федерации и меры по ее улучшению // Гигиена и санитария. 2009. № 2. C. 4-12.

[11] Лисиџын А.П. Маргинальный фильтр океанов // Океанология. 1994. Вып. 34. C. $735-747$.

[12] Потемкина Т.Г. Устья рек Байкала // Природа. 2014. № 12. С. 13-21.

[13] Очистка производственных сточных вод / сост. С.В. Яковлев, Я.А. Карелин, Ю.М. Ласков, Ю.В. Воронов. М.: Стройиздат, 1985. 336 с.

\section{References}

[1] Tkachev BP, Bulatov VI. Small rivers: state-of-the act and ecological problems: analytical review. Novosibirsk: SPSTL SB RAS; 2002.

[2] Astashin AE, Sotkina SA, Badin MM, Ryzhov EV, Samoilov AV. Dynamics of development of network of elementary water currents of the North of the forest-steppe zone of the Nizhny Novgorod region(on the example of the catchment basin of the river Sundovik) during 1984-2016. Bulletin of VSAWT. 2016;(48):15-24.

[3] Smirnova (Igonina) MV, Cheban EYu, Volodchenko EV, Berdnikova EYu, Solina ES. Hydro-ecological research of the Gorky and Cheboksary reservoirs sites and their tributaries in summer of 2017. Bulletin of VSAWT. 2017;4(53):98-108.

[4] Yasinskii SV, Venitsianov EV, Vishnevskaya IA. Diffuse pollution of water bodies and estimation of export of biogenic elements under different scenarios of water use in the watershed. Water Resources. 2019;46(2):232-244.

[5] Shaban VP. (ed.) Surface water resources of the USSR. Hydrological study. Vol. 10. Verkhne-Volzhsky district. Leningrad: Gidrometizdat Publ.; 1966.

[6] Astashin AE, Badin MM, Samoilov AV, Ryzhov EV, Vlasov AV, Fomina AI. Landscape structure of the territory of the Veletma watershed of the Nizhny Novgorod region. Natural and Technical Sciences Journal. 2019;(1):90-95. 
[7] Georgievskii VYu. (ed). Scientific and applied reference: the main hydrological characteristics river basins of the Upper Volga River. Livny: State Hydrology Institute, Mukhametov G.V. Publishing; 2015.

[8] Dzhamalov RG, Myagkova KG, Nikanorov AM, Reshetnyak OS, Safronova TI, Trofimchuk MM. Hydrochemical runoff of the Oka basin's rivers. Water and Ecology. 2017;4(72):26-39. http://dx.doi.org/10.23968/2305-3488.2017.22.4.26-39

[9] Tereshina MA, Sokolov DI, Erina ON, Vilimovich EA. Natural background or human impact: water quality of the Linda and Kudma rivers. Problems of Ecology of the Volga Basin: Proceedings of the 4th All-Russian Scientific Conference. Nizhniy Novgorod: VSUWT; 2019. p. 28.

[10] Onishchenko GG. Hygienic evaluation of the population of the Russian Federation with drinking water and measures for its improvements. Hygiene and Sanitation. 2009;(2):4-12.

[11] Lisitsyn AP. A marginal filter of the oceans. Oceanology. 1994;(34):735-747.

[12] Potemkina TG. Baikal rivers estuaries. Priroda. 2014;(12):13-21.

[13] Yakovlev SV, Karelin YaA, Laskov YuM, Voronov YuV. (eds.) Industrial wastewater treatment. Moscow: Stroiizdat Publ.; 1985.

\section{Сведения об авторах:}

Смирнова Мария Валерьевна, кандидат технических наук, доцент кафедры гидродинамики, теории корабля и экологической безопасности судов, Волжский государственный университет водного транспорта. ORCID: 0000-0002-3483-5482, eLIBRARY SPIN-код: 6961-2470, eLIBRARY AuthorID: 641567. E-mail: igoninam@yandex.ru

Батанина Анастасия Игоревна, студент 3-го курса направления подготовки «Техносферная безопасность», Волжский государственный университет водного транспорта. E-mail: nbatashka@gmail.com

\section{Bio notes:}

Maria V. Smirnova, Cand. Tech. Sci., Associate Professor of the Department of Hydrodynamics, Theory of the Ship and Environmental Safety of Vessels, Volga State University of Water Transport. ORCID: 0000-0002-3483-5482, eLIBRARY SPIN-code: 6961-2470, eLIBRARY AuthorID: 641567. E-mail: igoninam@yandex.ru

Anastasia I. Batanina, 3rd year student of the "Technosphere Safety" course, Volga State University of Water Transport. E-mail: nbatashka@gmail.com 